\title{
PUERTO RICO: THE QUEST FOR A "NATIONAL" ANTHEM
}

[Received 27th February 2017; accepted 7th September 2017 - DOI: 10.21463/shima.11.2.15]

\section{Valérie Vézina}

Memorial University of Newfoundland < valerie.vezina@mun.ca>

\begin{abstract}
Since the end of the Spanish-American War in 1898, Puerto Rico has been under the control of the United States. As an unincorporated territory of the United States, Puerto Rico has a separate identity that manifests itself in various ways. One of the most evident ones is through language, Spanish being the lingua franca for more than $90 \%$ of Puerto Ricans. But its nationalist stance is also found in symbols, such as its anthem. Although Puerto Rico adopted an official anthem in 1952, there has been a continuing quest for one that truly expresses the territory. The 'Star-Spangled Banner' is sometimes played but there is a more interesting story regarding 'La Borinqueña', the official anthem of Puerto Rico. Two opposing versions of this anthem exist. What is the story behind them? What is the meaning of each of those versions? Which version is the official version? This paper will address those questions and link them to the particular political status of Puerto Rico.
\end{abstract}

KEY WORDS: Nationalism, islandness, symbols, national anthem(s), Puerto Rico

\section{Introduction}

In an epic final at the 2016 Rio Olympic Games, tennis player Monica Puig, representing Puerto Rico, won the Olympic Gold; a first for the Caribbean island. Days before the final, there were many questions being asked: What is the national anthem of Puerto Rico? As a US territory, does it sing the 'Star-Spangled Banner'? Does the Olympic Committee even have a version of Puerto Rico's national anthem?' (Unattributed 2016a, 2016b: online). Following Puig's historic victory and the award of medals, 'La Borinqueña' started to play; tears filled Puig's eyes and the world, for the first time, heard the Puerto Rican anthem. A real fairy tale story. But the story does not stop here. To further complicate things, Puerto Rico's unique territorial and political status (and the state of political limbo it leaves the island in) has resulted in it having conflicting anthems. While the version of the song 'La Borinqueña' heard at Puig's Olympic ceremony is the 'official' version, there are at least two competing ones without forgetting the rather complicating relation Puerto Rico has with the United States and the playing, at times, of the 'Star-Spangled Banner'. In order to understand the quest for a Puerto Rican anthem, this article will start by examining the importance of symbols, and more specifically of anthems, to represent nation and subnational communities. Then, a brief summary of Puerto Rico's history and status will lead to a discussion of islandness and the separate identity of Puerto Rico, hence permitting an understanding of the conflicts over the anthem(s). Finally, a comparison between the two versions of 'La Borinqueña' will allow a better understanding of the internal debate over the meaning of Puerto Rico's anthem in the context of nationalism and islandness.

\footnotetext{
${ }^{1}$ Those are but a few examples of the newspaper headlines and articles published upon Puig's victory.
} 


\section{Vézina: Puerto Rico: The Quest for a 'National' Anthem}

\section{Anthems: A Powerful Musical Symbol of National Affirmation}

In a seminal work entitled Banal Nationalism (1995) Billig affirms that nationalism is not something that happens spontaneously but rather that for a nation to continue to exist, there must be a routinisation process whereby citizens are reminded of symbols in an almost unconscious manner. As he says:

The citizens of an established nation do not, day by day, consciously decide that their nation should continue. On the other hand, the reproduction of a nation does not occur magically. Banal practices, rather than conscious choice or collective acts of imagination, are required (ibid: 95).

Among "banal practices", Billig names the flag and the national anthem as important symbols of a nation. For him, a national anthem "is a universal sign of particularity" (ibid: 86). Billig is not the only one affirming the importance of national anthems for nations. Benedict Anderson highlights the important role played by national anthems in the process of the "imagined community":

Take national anthems, for example, sung on national holidays. No matter how banal the words and mediocre the tunes, there is in this singing an experience of simultaneity. At precisely such moments, people unknown to each other utter the same verses to the same melody. The image: unisonance. Singing... provide occasions for unisolanity, for the echoed physical realization of the imagined community (2006: 145).

That people unknown to each other feel bound, feel pride, feel united through the powerful symbol that is the national anthem is key to the development and maintenance of the nation. As Gunther Eyck summarises:

In itself, nationalism was a complex phenomenon with multiple cultural, economic, social, and political layers. But its incandescent core was psychological in nature, a spontaneous association with the concerns and hopes of countless compatriots. Giving voice to their aspirations or frustrations constituted the basic stimulus in the creation of national anthems (1995: xiii).

However, for a national anthem to rally all, it must become a national tradition and be popularly used (ibid: xix). In order for that to be accomplished, it appears that national anthems truly become national symbols if they fulfill a set of three functions outlined by Abril (2012: 85-87). First, an anthem must fulfill an emotional function. Here, music serves as an expression of emotions and as a vehicle of emotions that could not be attained otherwise. The second function is symbolic, in other words, the national anthem needs to be recognised as a national symbol. This recognition must come from both the political elite and the people. An anthem that is officialised by the state as such but not recognised by the people is incomplete in performing this second function. Finally, a national anthem contributes to the integration in society by providing a rallying point. This is the third function and, as Hebert and Kertz-Welzel remind us: "[e]ducating loyal citizens through patriotic songs... has been widely considered an acceptable, even crucial, part of the music education curriculum worldwide" (2012: 1). Not surprisingly then we accept that children rise up and sing the national anthem at schools or that there is such solemnity when the national anthem is sang at sports events or ceremonial events. But our puzzle still remains:

Shima Volume 12 Number 122017 
does Puerto Rico's anthem meet the three functions outlined by Abril? In order to answer this question, it is important to understand Puerto Rico's political situation.

\section{On the fence: Puerto Rico's territorial status}

Puerto Rico is an American territory with a population of around 3.4 million. The island is not a constituent member of the American federation; rather, it belongs to it, and is therefore subject to the plenary powers of the United States Congress. The United States Supreme Court stated, at the beginning of the 2oth Century, that Puerto Ricans were "foreign in a domestic sense" (Duffy Burnett and Marshall, 2001). Puerto Rico was under Spanish colonial rule for more than 400 years, and it did not acquire self-government until 1897. That year, as the last pieces of its colonial empire were falling, Spain allowed for Puerto Ricans to have representation in Madrid, an autonomous government, and their own constitution (Fernandez, 1992). However, this moment of partial emancipation was short-lived as the Spanish-American War resulted in Puerto Rico being given to the US as compensation for financial and material losses incurred during the conflict. For the United States, the issue then became what to do with the island (Fernandez, 1992: 4). Until 1900, Puerto Rico was under martial law. The 1900 Foraker Act provided for a civil government for Puerto Rico, although a governor was appointed by the US President with power to cancel and overrule any law voted on the island. Furthermore, with this Act, Puerto Rico was given a voice in Congress through the creation of the position of Resident Commissioner. But the Resident Commissioner's voice is quite limited as he/she cannot vote at Congress and can only speak when invited to and on matters related to the Island.

Some clarification on the political and constitutional nature of the relationship between the United States and Puerto Rico came via a series of court decisions, known as the Insular Cases, rendered at the turn of the 2oth Century. Three important specifications were made by the courts. The first was that Puerto Rico belonged to the United States but was not part of the American federation (Fernandez, 1992: 92). This point came with, and from, a doctrinal innovation featuring a distinction between "incorporated" and "unincorporated" territories. Puerto Rico was deemed an "unincorporated" territory of the United States, which meant that not all provisions of the United States constitution automatically applied to the Island (Rivera-Ramos, 2013). At the same time, the court specified that Puerto Rico represented an "organised" territory of the United States insofar as it featured executive, legislative and judicial branches making up a government for the Island. The second specification, grounded in the Territorial Clause of the United States constitution (Article IV, section 3, clause 2), was that Puerto Rico was subject to the "plenary power" of the United States Congress (Lawson and Sloane, 2009: 1127, 1131). This power, the court said, was not arbitrary and unlimited since Puerto Ricans, because they lived under the authority of the United States, did enjoy some "fundamental rights" (Rivera-Ramos, 2013: 96). The third specification was that Puerto Ricans were not "aliens" to the United States. This derives from the Jones Act passed by the United States Congress in 1917 that conferred American citizenship to residents of Puerto Rico. Through this Act, Puerto Ricans were given the potential capacity to move to the mainland and immediately become "equal" to continental US citizens when they did.

The existing status of Puerto Rico was finalised after the Second World War. In 1950, the US Congress's Public Law 600 authorised Puerto Rico to adopt its own constitution. In 1952, Puerto Rico's Estado Libre Asociado (ELA) (or 'Commonwealth' in English) was

Shima Volume 12 Number 122017 
formally established after approval by the population in a referendum and by the United States Congress. In the referendum, almost $80 \%$ of voters supported the establishment of the ELA, although the participation rate was less than $55 \%$, which is a low turnout for Puerto Rico (Pantojas, 2013: 44). In a nutshell, the ELA status means that residents of Puerto Rico hold US citizenship, serve in the military, are represented in the House of Representatives by a Resident Commissioner elected to a four-year term who does not have privileges to vote on the floor of the House, are subject to federal laws and are beneficiaries of federal aid as approved by Congress, do not vote in national elections, and pay no federal income tax.

For many authors, the relationship between Puerto Rico and the United States is fundamentally colonial (although the referendum on ELA allowed the United States to have the island removed from the United Nations list of non-autonomous territories). For Martínez:

the establishment of Commonwealth was used to create the myth - both for internal and external consumption - that Puerto Ricans exercised the right to self-determination because in 1952 they accepted Commonwealth in a yes-or-no referendum. (1977: 567)

Recent developments, namely a Supreme Court of the United States' case featuring a revealing Amicus brief ${ }^{2}$ on the part of the United States' Solicitor General (see PR51st, 2015: online) and the 2016 Puerto Rico Oversight, Management, and Economic Stability Act (PROMESA) legislation of the United States Congress, provide additional grounds to the claim that the relationship between the United States and Puerto Rico is colonial.

Despite (and likely because of) the colonial nature of its relationship with the United States, Puerto Ricans have developed a unique sense of identity. Nationalism is multidimensional, often draws from a sense of distinctiveness and can be constituted by cultural, economic and political forces. For Puerto Rico, one distinctive aspect is its location - comprising one main island and a small number of outliers (Figure 1). Its sense of distinctiveness is thus partly shaped by its geography and its islandness. This is, as we will see later, reflected in its anthem.

Recently, social scientists have started to become interested in the connection between islands and national identities. As Baldacchino suggests, islands are "platforms for the emergence of national identity and for the affirmation of cultural specificity. As prototypical ethno-spaces, islands have spearheaded the study of the production of locality" (2006: 4) According to Hay, identity is constructed around a state of mind very much linked to territoriality: "the nature of the community-its mythology, imagination, its very soul-has been sculpted by its geographical circumstances" (2006: 22). Islandness can therefore become part and parcel of nationhood (Baldacchino, 2006, 2007; Conkling, 2007; Fazi, 2012; Hepburn, 2010, 2012). For Fazi and Hepburn, the geographical distance between an island and the state that controls it impacts nationalist demands. Both hypothesise that the closer an island is to the state, the weaker demands for more power and autonomy (Fazi, 2012: 149; Hepburn, 2012: 130). According to the scale offered by Fazi, Puerto Rico would be somewhat far away. The physical distance between Puerto Rico and the mainland United States might help explain why self-identification data reveal that

\footnotetext{
${ }^{2}$ An Amicus brief is a legal document filed in an appellate court case by non-litigants with a significant interest in the issue concerned.
}

Shima Volume 12 Number 122017 


\section{Vézina: Puerto Rico: The Quest for a 'National' Anthem}

Puerto Ricans "professed a remarkable consistency and depth of fidelity to Puerto Rico. Almost as consistent was the absence of identification with the United States" (Morris, 1995: 125).

There may also be a link between, on the one hand, size and population, and, on the other hand, national identity. For McCall, a big island is more likely to have more territorial cleavages than a small island. The more territorial cleavages there are, the less people feel they are members of the same political community (1994: 96). The main island of Puerto Rico, on which close to $99 \%$ of its population reside, ${ }^{3}$ is fairly compact ( $9104 \mathrm{~km} 2$ - see Figure 1), which may have contributed to its residents' sense of nationhood.

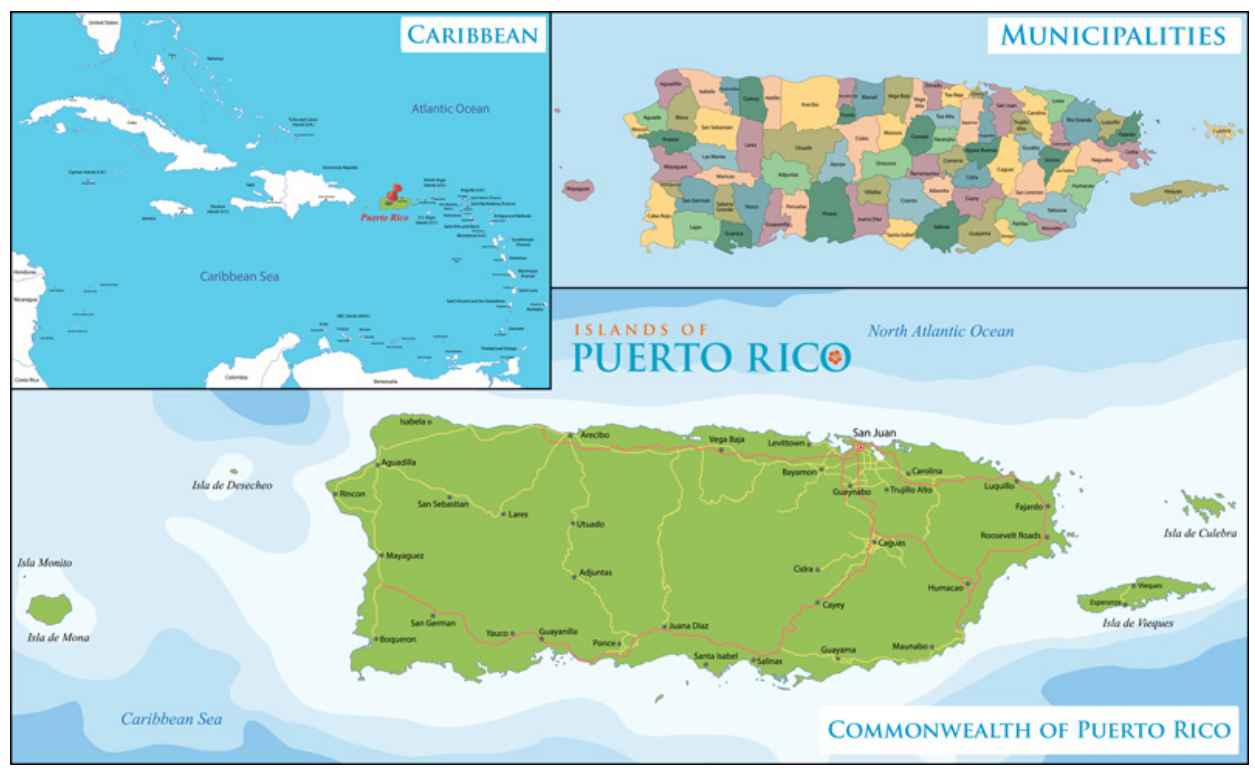

Figure 1 - Maps of Puerto Rico and surrounding islands and its position in the Caribbean (Source: Islandsofpuertorico.com)

The sense of islandness and separate identity was further cemented by the United States' attempt, in the first half of the 2oth Century, to assimilate Puerto Ricans to what might be termed "the American way of life". This was done through various means. The most contentious one was the establishment of English as the official language of the territory and the official language of instruction. As Malavet explains:

\section{The official attempts to "Americanize" Puerto Rico included well-orchestrated efforts to encourage and "American," rather than a Puerto Rican, form of patriotism... Public displays of pro-United States "patriotism" and honoring "American" symbols were required (2004: 115).}

Among such displays was the singing of the 'Star-Spangled Banner'. Those requirements were maintained until the first-elected governor, Luis Muñoz Marin, took office in 1948

\footnotetext{
${ }^{3}$ Around 9,ooo people also reside on Isla de Vieques and around 1,80o on Isla Culebra.
} 


\section{Vézina: Puerto Rico: The Quest for a 'National' Anthem}

and re-established Spanish as the official language of Puerto Rico in 1949. In 1952 he followed this by authorising 'La Borinqueña' as the official anthem in 1952.

\section{The Story of 'La Borinqueña'}

The story of 'La Borinqueña' dates back to the 19th Century and its origins are contentious. Deliz (1980) has identified that the song might have had been influenced by Peruvian or Cuban songs. The music for 'La Borinqueña' was composed by Félix Astol Artés in 1867 with Lola Rodríguez de Tío adding lyrics in the following year. In 1868 the song became a revolutionary call against the colonial power (at that time Spain) in 1868 . The lyrics speak for themselves:

\begin{tabular}{|c|c|}
\hline Original version $^{4}$ & English translation \\
\hline $\begin{array}{l}\text { ¡Despierta, borinqueño } \\
\text { que han dado la señal! } \\
\text { ¡Despierta de ese sueño } \\
\text { que es hora de luchar! } \\
\text { A ese llamar patriótico } \\
\text { ¿no arde tu corazón? } \\
\text { ¡Ven! Nos será simpático } \\
\text { el ruido del cañón. } \\
\text { Mira, ya el cubano } \\
\text { libre será; } \\
\text { le dará el machete } \\
\text { su libertad... } \\
\text { le dará el machete } \\
\text { su libertad. } \\
\text { Ya el tambor guerrero } \\
\text { dice en su son, } \\
\text { que es la manigua el sitio, } \\
\text { el sitio de la reunión, } \\
\text { de la reunión... } \\
\text { de la reunión. } \\
\text { El Grito de Lares } \\
\text { se ha de repetir, } \\
\text { y entonces sabremos } \\
\text { vencer o morir. } \\
\text { Bellísima Borinquén, } \\
\text { a Cuba hay que seguir; } \\
\text { tú tienes bravos hijos } \\
\text { que quieren combatir. } \\
\text { ya por más tiempo impávido } \\
\text { no podemos estar, } \\
\text { ya no queremos, tímidos } \\
\text { dejarnos subyugar. } \\
\text { Nosotros queremos } \\
\text { ser libre ya, } \\
\text { y nuestro machete } \\
\text { afilado está. } \\
\text { y nuestro machete } \\
\text { afilado está. }\end{array}$ & $\begin{array}{l}\text { Arise, boricua! } \\
\text { The call to arms has sounded! } \\
\text { Awake from the slumber, } \\
\text { it is time to fight! } \\
\text { Doesn't this patriotic } \\
\text { call set your heart alight? } \\
\text { Come! We are in tune with } \\
\text { the roar of the cannon. } \\
\text { Come, Come, the Cuban will } \\
\text { soon be freed; } \\
\text { the machete will give him } \\
\text { his justice, } \\
\text { the machete will give him } \\
\text { his liberty. } \\
\text { Now the drums of war } \\
\text { speak with their music, } \\
\text { that the jungle is the place, } \\
\text { the meeting place. } \\
\text { The meeting... } \\
\text { The meeting... } \\
\text { The Cry of Lares } \\
\text { must be repeated, } \\
\text { and then we will know: } \\
\text { victory or death. } \\
\text { Beautiful Borinquén } \\
\text { must follow Cuba; } \\
\text { you have brave sons } \\
\text { who wish to fight. } \\
\text { Now, no longer can } \\
\text { we be unmoved; } \\
\text { now we do not want timidly } \\
\text { to let them subjugate us. } \\
\text { We want to be free now, } \\
\text { and our machete } \\
\text { has been sharpened. } \\
\text { We want to be free now, } \\
\text { and our machete } \\
\text { has been sharpened. }\end{array}$ \\
\hline
\end{tabular}

\footnotetext{
${ }^{4}$ The Spanish version is found in Deliz (1980). The English translation is mine.
} 


\begin{tabular}{|l|l|}
\hline ¿Por qué, entonces, nosotros & Why, then, \\
hemos de estar, & have we been \\
tan dormidos y sordos & so sleepy and deaf \\
y sordos a esa señal? & to the call? \\
a esa señal, a esa señal? & To the call, to the call? \\
No hay que temer, riqueños & There is no need to fear, \\
al ruido del cañón, & Ricans, the roar of the cannon; \\
que salvar a la patria & saving the nation is \\
es deber del corazón! & the duty of the heart. \\
ya no queremos déspotas, & We no longer want despots, \\
caiga el tirano ya, & tyranny shall fall now; \\
las mujeres indómitas & the unconquerable women also \\
también sabrán luchar. & will \\
Nosotros queremos & know how to fight. \\
la libertad, & We want freedom, \\
y nuestros machetes & and our machetes \\
nos la darán... & will give it to us. \\
y nuestro machete & We want freedom, \\
nos la dará... & and our machetes \\
Vámonos, borinqueños, & will give it to us. \\
vámonos ya, & Come, Boricuas, \\
que nos espera ansiosa, & come now, \\
ansiosa la libertad. & since freedom \\
¡La libertad, la libertad! & awaits us anxiously, \\
& freedom, freedom! \\
\hline
\end{tabular}

In this version, not only is the call to arms made clear by the repetition of the word "machete" but it is also posed as the only way to access to freedom (as the repetition at the end clearly shows). This anthem, as Carríon points out, "originates in 19th-century anticolonial struggles... (it) is set to music that invites one to dance [and] is based on a type of music called la danza" (2008: 844). The "Cry of Lares" mentioned in the anthem is a revolt against Spain that took place in the town of Lares in 1868 attempting to establish the Republic of Puerto Rico. It was crushed by Spain but was a determining factor in the creation of a strong sense of nationalism. In the myth of the formation of the nation in Puerto Rico, Ramón Emeterio Betances is often depicted as the Padre de la Patria (father of the nation). He was one of the instigators of the Revolt in Lares.

The musical style used in the anthem, la danza, originated in Ponce (the country's second largest city) in the south of the Island (see Figure 1). The danza is rich in melodic and harmonic contents and some compositions in the idiom are melancholic and romantic with long phrases, rich harmonies and three or more clearly defined parts. Others are fast and lively short pieces of a playful character. Either way, it is composed of patterns that invite one to dance (Carríon, 2008: 844). Traditionally a danza consists of four parts: an introduction or paseo (usually of 8 measures) and then a first, second and third theme, each of 16 measures. The third theme is usually more lively or melodic and in it the bombardino (a type of euphonium) leaves its standard role as accompanist and becomes the soloist. After the third theme there is a recapitulation of the first theme and sometimes a coda for the end. All parts except the coda and recapitulation are played twice. There might be variations to this, such as the introduction of bridge parts of 8 measures instead of 16. Although danzas are mostly romantic, they are characterised by a distinct rhythmic accompaniment, played by the left hand when at the piano or by a bombardino in orchestras. 


\section{Vézina: Puerto Rico: The Quest for a 'National' Anthem}

When the United States invaded Puerto Rico in 1898 during the Spanish-American War, 'La Borinqueña' was a well-known and popular song (Deliz, 1980: 24). However, the new governing and colonial power thought the lyrics of the anthem were too subversive and invited authors, through a contest, to submit new lyrics. In 1903, lyrics by Manuel Fernández Juncos replaced the earlier version and this new 'Borinqueña', became the official anthem. As Carríon has characterized, 'La Borinqueña' was "adopted as the anthem of the new self-governing regime but was modified to purge its separatist connotations" (2008: 844). The lyrics of the Fernández Juncos' version are as follows:

\begin{tabular}{|c|c|}
\hline Original version $^{5}$ & English translation \\
\hline $\begin{array}{l}\text { La tierra de Borinquen } \\
\text { donde he nacido yo } \\
\text { es un jardín florido } \\
\text { de mágico primor. } \\
\text { Un cielo siempre nítido } \\
\text { le sirve de dosel. } \\
\text { Y dan arrullos plácidos } \\
\text { las olas a sus pies. } \\
\text { Cuando a sus playas llegó } \\
\text { Colón; } \\
\text { Exclamó lleno } \\
\text { admiración; } \\
\text { "Oh!, oh!, oh!, } \\
\text { Esta es la linda tierra } \\
\text { que busco yo." } \\
\text { Es Borinquen la hija, } \\
\text { la hija del mar y el sol, } \\
\text { Del mar y el sol, } \\
\text { Del mar y el sol, } \\
\text { Del mar y el sol, } \\
\text { Del mar y el sol. }\end{array}$ & $\begin{array}{l}\text { The land of Borinquen } \\
\text { where I was born } \\
\text { is a flowery garden } \\
\text { of magical beauty. } \\
\text { A constantly clear sky } \\
\text { serves as its canopy. } \\
\text { And placid lullabies are sung } \\
\text { by the waves at its feet. } \\
\text { When at her beaches Columbus } \\
\text { arrived; } \\
\text { he exclaimed full of admiration } \\
\text { "Oh! Oh! Oh! } \\
\text { This is the beautiful land } \\
\text { that I seek." } \\
\text { Borinquen is the daughter, } \\
\text { the daughter of the sea and the } \\
\text { sun. } \\
\text { Of the sea and the sun, } \\
\text { Of the sea and the sun, } \\
\text { Of the sea and the sun, } \\
\text { Of the sea and the sun. }\end{array}$ \\
\hline
\end{tabular}

Far from the original call for arms, Juncos's version speaks of the natural (and magical) beauty of the island. The repetition of the words "sea" and "sun" at the end emphasise the paradisiacal nature of Puerto Rico and the chorus states that the island is "the daughter of sea and sun" (la hija del mar y el sol), demonstrating the importance of the sea and hence, of the geographical factor. Furthermore, the island is popularly known as la Isla del encanto ("the island of enchantment"), emphasising the island condition of Puerto Rico as an integral and important part of its identity. Other words such as "magical" and "beautiful" only reaffirm that this second version of the song is soft and is not intended to inspire revolt. It should be noted that the original music was also altered. The introductory paseo was taken off and Ramón Callado restyled the musical arrangement to sound more like a march. It was this version of the composition that was officially adopted as the Puerto Rican anthem with the signature of Law \#2 on July 24 th 1952.

\footnotetext{
${ }^{5}$ The official lyrics can be found on the government of Puerto Rico webpage at:

http://www2.pr.gov/SobrePuertoRico/Pages/Himnos-Nacionales.aspx. Again, the translation is mine.
} 


\section{The two 'Borinqueñas'}

As the previous section has demonstrated, the two versions of the anthem's lyrics have considerably different meanings. Carríon summarises it perfectly, stating that the "original revolutionary lyrics of 'La Borinqueña' were changed to an innocuous rendition of the country's beauty" (2008: 844). Deliz also asserts that the second version primarily emphasises the beauty of the land as well as the deep sentiments people have towards the Island (1980: 42). This change of meaning certainly leads to ambiguity especially when one considers the three aforementioned functions of national anthems. The first function relates to emotions that arise from the anthem. There are conflicting emotions in the two versions: the first is informed by frustration and anger and promotes revolt and fighting. The second version attenuates (even eliminates) those emotions to replace them with peaceful and loving emotions of one's land and feelings of love, peacefulness and happiness emerge.

The second, symbolic function, stipulates that the anthem must be recognised as a national symbol. Interestingly, although 'La Borinqueña' was proclaimed as the Puerto Rican anthem by Law \#2 in 1952, the law only recognised the musical composition as that anthem. The words (or lyrics) were not officially prescribed until 1977. Hence, for a substantial period of its history (since the composition of the first anthem), Puerto Rico did not have a single recognised anthem but, rather, competing anthems. It should also not be forgotten that up until 1949, the US national anthem acted as the official anthem of Puerto Rico. There are hence three conflicting anthems that played an important role in the history of the Island. Finally, it is worth mentioning that the Rodriguez's revolutionary version is still played at some events; most notably at the annual festival staged by the proindependence newspaper Claridad. ${ }^{6}$ Throughout this event the anthem is played and sang loudly by people attending. At other official (i.e. government organised) events, it is the official anthem that is played. With regard to the second function of anthems there is certainly a duality. It is interesting here to compare the case of Puerto Rico to that of another island jurisdiction, Jersey. As Johnson (2015) has detailed, despite an official competition to find an anthem for the Island the winning entry was not adopted by the local government, resulting in various "anthems" being played at different occasions. The situation in Puerto Rico is somewhat similar, as various anthems are in competition with one another. However, unlike in Jersey, the government of Puerto Rico has officially adopted an anthem. The problem resides, just like in Jersey, in making it truly recognised by the public, in other words, making it an anthem that links all members of the "imagined community" of Puerto Rico.

The third, integrative function, asserts that anthems are useful devices to educate loyal and patriotic citizens. The story gets even more complicated on this function due to the fact that up until 1949, the 'Star-Spangled Banner' was taught to children at school (and any version of 'La Borinqueña' was prohibited). With the adoption of the ELA status in 1952, the official Puerto Rican anthem was promulgated. But the latter also led to a resurgence of the revolutionary version, with pro-independence factions promoting its use amongst their supporters. Even today the two versions of 'La Borinqueña' are in conflict. Depending on which party is in government and, depending on which party is in power,

\footnotetext{
${ }^{6}$ Every February the newspaper hosts a festival to help finance its operation. The event lasts a full weekend and encompasses music shows, speeches and games for children. Entry is by donation and a large number of people (even those who do not necessarily support independence) regularly attend.
}

Shima Volume 12 Number 122017 


\section{Vézina: Puerto Rico: The Quest for a 'National' Anthem}

the 'Star-Spangled Banner' may also be played. Consistent with its focus, the Partido Nuevo Progresista (PNP), which advocates Puerto Rico becoming the 51st state of the United States of America), often plays the US anthem. Interestingly, the government, currently headed by the PNP states on its official webpage that there are national anthems (in the plural form) and flags (also used in the plural form). Of course, in both instances, it is the Puerto Rican and American ones that are referred to. ${ }^{7}$ Overall, as the previous analysis has demonstrated, none of the functions of national anthems are clearly fulfilled by any single anthem, which leads to a constant (and conflicting) quest for a true anthem for Puerto Rico.

\section{Conclusion}

Authors addressing nationalism have identified national symbols, such as anthems, as an important defining element of nations. Not only does an anthem allow a nation to distinguish itself from others but it also identifies what is particular, distinctive and unique about a single nation. To be most effective, national anthems have to perform emotional, symbolic and integrative functions. This article has sought to examine issues concerning Puerto Rico's anthem. As has been shown, there are overlapping functions among different versions of the 'La Borinqueña' anthem and that the presence of the StarSpangled Banner as the 'anthem' of Puerto Rico for half a century leads to even more complications. This overlapping and the presence of the US anthem is clearly linked to the political status of the Island. Despite Puerto Ricans having held five consultative referendums on their political status ${ }^{8}$, ultimately only the US Congress can altered Puerto Rico's situation. It is unclear what the US will do with Puerto Rico, one of the last colonies, but the status quo is certainly not optimal. Despite official laws, the official anthem in Puerto Rico is therefore still not quite national. What is interesting is that it seems that the debate over the anthem is also linked to which flag (the Puerto Rican or US flag) is displayed. It seems that only a resolution of the status issue can lead to a real affirmation of such national symbols.

An initial version of this paper was presented at the 13th International Small Island Cultures conference held in St. John's, Newfoundland in June 2017. The author is very thankful for comments and questions received.

\section{BIBLIOGRAPHY}

Abril, R (2012) 'A National Anthem: Patriotic Symbol or Democratic Action?', in Hebert, D. G and Kertz-Welzel, A (eds) Patriotism and Nationalism in Music Education, Farnham, Surrey; Burlington: Ashgate Publishing Company

Anderson, B (2006 [1991]) Imagined Communities: Reflections on the Origin and Spread of Nationalism, London; New York: Verso

\footnotetext{
${ }^{7}$ See: http://www2.pr.gov/SobrePuertoRico - accessed September 7th 2017.

${ }^{8}$ In June 2017, 97\% voted to become a state of the US. However, voter turnout was quite low (around 23\%) and it is unlikely that a pro-Republican Congress will admit a pre-dominant Spanish-speaking Island to the federation. The low turnout can be explained by a call to boycott the referendum by the other political parties. For more on the politics of the status, see: Lecours and Vézina (forthcoming).
}

Shima Volume 12 Number 122017 


\section{Vézina: Puerto Rico: The Quest for a 'National' Anthem}

Baldacchino, G (2006) 'Islands, Island Studies, Island Studies Journal,' Island Studies Journal vi no1: 3-18

Baldacchino, G (2007) A World of Islands: An Island Studies Reader, Charlottetown PEI: Island Studies Press

Berríos Martínez, R (1977) 'Independence for Puerto Rico: The Only Solution', Foreign Affairs no55: 561-83

Billig, M (1995) Banal Nationalism, London: Sage

Carrión, J. M (2008) 'Puerto Rico', in Herb, G. H and Kaplan, D. H (eds) Nations and Nationalism. A Global Historical Overview, Santa Barbara, California: ABC-CLIO, inc

Conkling, P (2007) 'On Islanders and Islandness,' The Geographical Review, v97 no2: 191201

Deliz, M (1980) 'El himno de Puerto Rico: Estudio Critico de la Borinqueña', in Natal, C. R (ed) Escudo, Himno y Bandera. Origen e Historia de los Símbolos de Puerto Rico, Río Piedras: Producciones Historicas

Duffy Burnett, C and Marshall, B (2001) Foreign in a Domestic Sense: Puerto Rico, American Expansion, and the Constitution, Durham: Duke University Press

Fazi, A (2012) 'Insularity and Autonomy: From a Misleading Equation to a New Typology,' In Gagnon, A.-G and Keating, M (eds.) Political Autonomy and Divided Societies. Imagining Democratic Alternatives in Complex Settings, Houndmills, Basingstoke, Hampshire; New York: Palgrave Macmillan: 134-154

Fernandez, R (1992) The Disenchanted Island. Puerto Rico and the United States in the Twentieth Century, New York: Praeger

Gunther Eyck, F (1995) The Voice of Nations, European National Anthems and Their Authors, Westport: Greenwood Press

Hay, P (2006) 'A Phenomenology of Islands,' Island Studies Journal v1 no1: 19-42

Hebert, D. G and Kertz-Welzel, A (2012) 'Introduction' in Hebert, D. G and Kertz-Welzel, A (eds) Patriotism and Nationalism in Music Education, Farnham/Burlington: Ashgate Publishing Company.

Hepburn, E (2012) 'Recrafting Sovereignty: Lessons from Small Island Autonomies?' In Gagnon, A.-G and Keating, M (eds.) Political Autonomy and Divided Societies: Imagining Democratic Alternatives in Complex Settings, Basingstoke/New York: Palgrave Macmillan: 118-133

Johnson, H (2015) 'Anthem for Jersey: Music, Media and Politics in an Island Setting,' MEDIANZ v15 no1: https://medianz.otago.ac.nz/medianz/article/view/132

Lawson, G and Sloane, R.D (2009) 'The Constitutionality of Decolonization by Associated Statehood: Puerto Rico's Legal Status Reconsidered', Boston College Law Review n4: 1123-93

Shima Volume 12 Number 122017 


\section{Vézina: Puerto Rico: The Quest for a 'National' Anthem}

Lecours, A and Vézina, V (forthcoming) 'The Politics of Nationalism and Status in Puerto Rico', Canadian Journal of Political Science

Malavet, P.A (2004) America's Colony: The Political and Cultural Conflict between the United States and Puerto Rico, New York: New York University Press

Morris, N (1995) Puerto Rico: Culture, Politics and Identity, Westport: Praeger Publishers

Pantojas-García, E (2013) 'The Puerto Rico status question: can the stalemate be broken?' Caribbean Journal of International Relations \& Diplomacy n1: 41-52

PR51st (2015) 'Amicus Brief for Puerto Rico': http://www.pr51st.com/amicus-brief-puertorico/ - accessed 8th September 2017

Rivera-Ramos, E (2013) 'Puerto Rico. Autonomy or Colonial Subordination?' In Ghai, Y and Woodman, S (eds) Practising Self-Government. A Comparative Study of Autonomous Regions, Cambridge: Cambridge University Press

Unattributed (2016a) 'JO 2016 - tennis : Monica Puig offre à Porto Rico sa première médaille d'or olympique', Le Monde: http://www.lemonde.fr/jeux-olympiques-rio2016/article/2016/o8/14/jo-2016-tennis-monica-puig-offre-a-porto-rico-sa-premieremedaille-d-or-olympique_4982485_4910444.html - accessed September 2nd 2017

----- (2016b) 'Monica Puig makes Puerto Rico gold medal history in women's singles', The Guardian: https://www.theguardian.com/sport/2016/aug/13/monica-puig-puerto-ricagold-medal-history-rio-2016-womens-singles-monique-kerber-tennis - accessed July 2017 